\title{
The Trump Administration's destruction of the Economic Research Service: An American Tragedy
}

\author{
Marion Nestle
}

The Trump Administration's plans to relocate much of the U.S. Department of Agriculture's Economic Research Service (ERS) out of Washington DC and into the American heartland over 1000 miles (1600 km) away-to Kansas City--indicates the lengths to which this administration will go to block information that does not support its pro-business agenda. By US government standards, the ERS is tiny. Its 2018 budget was about \$68 million, little more than a rounding error in the billions spent on other agencies. It employed only 330 social scientists, economists, and support staff. Nevertheless, and despite substantial opposition from organizations that depend on its work and from some members of Congress, most of staff members have been targeted for relocation and restructuring of their research focus.

In September 2018, the USDA Secretary, Sonny Perdue, proposed this relocation and reorganization ${ }^{1}$ of the ERS in order to, in the words of the President's budget proposal:

Bring these federal resources closer to the stakeholders the US Department of Agriculture (USDA) serves... This relocation would improve USDA's ability to attract and retain highly qualified staff with training and interests in agriculture, many of whom come from the land-grant universities dispersed across rural America. This proposal would also benefit American taxpayers. There would be potential for savings on employment costs given that the 28 percent locality pay for the national capital region is higher than the national average as well as potential savings on facilities and operations. ${ }^{2}$

None of these reasons bears up under even the most casual scrutiny.

In its March 2019 budget proposal, the Trump administration proposed to cut ERS’s funding by \$26 million in language straight out of George Orwell’s 1984: “The Budget would eliminate low priority research that is duplicative of research at land-grant universities, while still supporting ERS's core mission to develop the statistics needed to measure economic concepts in a dynamic farm and agricultural sector.”2 
Indeed, in a webinar following the Secretary's announcement, former USDA and ERS officials were unanimous in arguing that the proposals were "ill-conceived," made no sense, were set without appropriate consultation, were potentially illegal, would politicize the ERS, and would damage, if not destroy, it. ${ }^{3}$

At the time, I asked, “What is this really about?”4 My guess was that this was the Trump Administration's way to get political control over an agency of economists and researchers who conduct independent, unbiased, nonpartisan research that sometimes leads to inconvenient truths about policies this Administration dislikes.

ERS can be understood as the jewel in USDA's crown, nothing less than a national treasure, not only worth preserving, but worth extolling for its truly important contributions to society. I've long said that ERS was the best kept secret in government. Its researchers have worked tirelessly to provide real data-fact-based truths--on America's food production and consumption systems and what they mean for health.

As the agency's website explains (https://www.ers.usda.gov/about-ers/), ERS economists and social scientists produce analyses of a broad range of topics:

- Agricultural Economy - farm sector performance and farm households' wellbeing; farm size and concentration; market analysis, data, and projections on commodity supply, demand, and prices; and Federal farm policies

- Food and Nutrition - U.S. food security, food and nutrition assistance programs, food choices and health outcomes, food access and store proximity, food retailing and marketing, and food prices

- Food Safety - societal benefits associated with reducing food safety risks, economic impacts of food hazards, and potential results of regulation versus industry decisions

- Global Markets and Trade - major markets and competitors, economic impacts of exports and imports, trade barriers, and potential trade agreements

- Resources and Environment - economic impacts of conservation programs, efficacy of policies designed to protect the environment, and enhancing agricultural competitiveness through technology 
- Rural Economy - investments in rural communities and drivers of rural economic performance, demographic change and its impact on rural communities

These analyses are nonpartisan, appear unbiased, and are written in clear language that anyone, even congressional representatives, can understand.

As it became clear that the USDA would move ahead with its plans despite opposition, many ERS professional staff took retirement or resigned,,$\frac{5}{}$ and others spoke out on this "crackdown on research that's unflattering to White House policy priorities." ${ }^{6}$ Even more remarkable, ERS staff joined a union that would bargain for their rights. ${ }^{7}$

According to Politico, ERS staff have compared the list of researchers who are remaining in Washington, DC, with the list of those who have been told they must move to the new location. The researchers to be transferred are largely specialists in issues like climate change, food assistance programs, and trade policy. Economic assessments of those issues tend to disagree with the Administration's views and policies. These lists indicate that employees remaining in the District are specialists in less controversial areas such as crop planting. ${ }^{6}$

Some members of the House of Representatives are trying to block the relocation. Eight Democratic senators led by Sen. Chris Van Hollen (D-Md.) co-sponsored a measure that would prevent USDA from moving any part the ERS. Van Hollen is also trying another route: he has put a hold on the nomination of Scott Hutchins to be USDA's chief economist. ${ }^{8}$ But even if these measures succeed, the damage will have already be done. By the time any legislation gets passed, the move will already have been accomplished and key ERS researchers will have already abandoned the agency.

As further evidence that this move is about politics, not cost-savings, a cost-benefit analysis by the Agricultural and Applied Economics Association (AAEA) thoroughly refutes the USDA's claim that the move will benefit taxpayers. By its estimate, moving the ERS to Kansas City will incur a net cost increase of $\$ 83$ to $\$ 182$ million. $^{9}$ 
ERS was not broken, and did not need fixing. This agency produces authoritative, clear, understandable analyses of food and nutrition issues that I and many others rely on for our work. I consider this loss to be incalculable, and nothing less than a national tragedy.

Marion Nestle is Paulette Goddard Professor of Nutrition, Food Studies, and Public Health, Emerita, at New York University. This article is based on several posts on her blog, foodpolitics.com, and reflects events through June 22, 2019.

\section{Endnotes}

${ }^{1}$ USDA. Press release: USDA to Realign ERS with Chief Economist, Relocate ERS \& NIFA Outside DC. August 9, 2019. https://www.usda.gov/media/press-releases/2018/08/09/usdarealign-ers-chief-economist-relocate-ers-nifa-outside-dc

${ }^{2}$ U.S. Government. A Budget for A Better America: Promises Kept. Taxpayers First. Major Savings and Reforms. March 11, 2019. https://www.whitehouse.gov/wpcontent/uploads/2019/03/budget-fy2020.pdf.

${ }^{3}$ USDA Research Relocation and Reorganization: Perspectives from Former USDA Chief Scientists and Administrators. Association of Public Data Users, September 20, 2019. http://apdu.org/2018/09/21/usda-research-relocation-and-reorganization-perspectives-fromformer-usda-chief-scientists-and-administrators/

${ }^{4}$ Nestle M. USDA's double-speak proposal to “improve” the ERS: brute-force politics. September 21, 2018. https://www.foodpolitics.com/2018/09/usdas-double-speak-proposal-toimprove-the-ers-crude-politics/

${ }^{5}$ Guarino B. USDA researchers quit in droves as Trump administration plans relocation. Washington Post, May 23, 2019. https://www.washingtonpost.com/science/2019/05/22/usdaresearchers-quit-droves-trump-administration-plans-relocation/?utm_term=.640ef6f39351

${ }^{6}$ Crampton L. USDA farms out economists whose work challenges Trump policies. Politico, May 22, 2019. https://www.politico.com/story/2019/05/22/usda-agriculture-economists-trumppolicies-1340168

${ }^{7}$ Ogrysko N. Faced with possible relocation, USDA's ERS employees vote to unionize. Federal News Network. May 9, 2019. 
https://federalnewsnetwork.com/unions/2019/05/faced-with-possible-relocation-usdas-ersemployees-vote-to-unionize

${ }^{8}$ Van Hollen C. Press release: Van Hollen, Democrats question USDA plans to relocate offices outside the national capital region. May 14, 2019. https://www.vanhollen.senate.gov/news/press-releases/van-hollen-democrats-question-usdaplans-to-relocate-offices-outside-the-national-capital-region ${ }^{9}$ Agricultural and Applied Economics Association. AAEA review finds that USDA benefit-cost analysis underestimates the true cost of relocating researchers to Kansas City June 19, 2019. https://www.aaea.org/UserFiles/file/Report-MovingUSDAResearchersWillCostTaxpayers$\underline{\text { AAEAReport2019june19final.docx.pdf }}$ 